\title{
REFINANSOWANIE KREDYTU UDZIELONEGO KONSUMENTOWI PRZEZ RÓŻNE PODMIOTY POWIAZZANE KAPITAŁOWO BAZDŹ OSOBOWO JAKO PRAKTYKA NARUSZAJĄCA ZBIOROWE INTERESY KONSUMENTÓW
}

\author{
Magdalena Paleczna \\ Wydział Prawa, Administracji i Ekonomii, Uniwersytet Wrocławski \\ ORCID: https://orcid.org/0000-0001-7646-1055
}

\begin{abstract}
Streszczenie
W praktykach rynkowych kredytodawców kredytu konsumenckiego zaobserwować można pewne nieprawidłowości. Jedną z nich jest refinansowanie kredytu konsumenckiego udzielonego konsumentowi przez różne podmioty powiązane kapitałowo bądź osobowo. Jest to zjawisko, które uwidoczniło się w działaniach kredytodawców na przestrzeni kilku ostatnich lat i było przedmiotem analiz zarówno Rzecznika Finansowego, jak i Prezesa Urzędu Ochrony Konkurencji i Konsumentów. Celem niniejszego artykułu jest przedstawienie zjawiska polegającego na refinansowaniu kredytu udzielonego konsumentowi przez różne podmioty powiązane kapitałowo bądź osobowo jako próby obejścia stosowania art. 36a i art. 36c ustawy z dnia 12 maja 2011r. o kredycie konsumenckim, i tym samym uznanie za praktykę naruszającą zbiorowe interesy konsumentów zgodnie $z$ art. 24 ust. 1 i ust. 2 ustawy z dnia 16 lutego 2007 r. o ochronie konkurencji i konsumentów.
\end{abstract}

Słowa kluczowe: refinansowanie kredytu, praktyka naruszająca zborowe interesy konsumentów, ochrona konsumenta, kredyt konsumencki.

JEL Class: G18, G19, G23, G28. 


\section{WSTEPP}

Na przestrzeni kilku ostatnich lat w praktykach rynkowych kredytodawców ${ }^{1}$ kredytu konsumenckiego ${ }^{2}$ zaobserwować można wiele zróżnicowanych nieprawidłowości [zob. Raport Rzecznika Finansowego 2018; Raport Doradczego Komitetu Naukowego 2019: 75-95, 351-363]. Zazwyczaj są to działania niezgodne z obowiązującymi przepisami prawa, w szczególności ustawy z dnia 12 maja $2011 \mathrm{r}$. o kredycie konsumenckim [T.j. Dz.U. 2019, poz. 1083, dalej: ustawa o kredycie konsumenckim lub u.k.k.] oraz sprzeczne z dobrymi obyczajami. Praktyki rynkowe kredytodawców kredytu konsumenckiego zagrażają indywidualnym interesom konsumentów, jak również mają wpływ na szerszy krąg uczestników rynku konsumenckich usług kredytowych.

Wobec dużej liczby nieprawidłowości stwierdzonych przez Rzecznika Finansowego i Prezesa Urzędu Ochrony Konkurencji i Konsumentów, związanych z naliczaniem i pobieraniem przez kredytodawców zbyt wysokich, często nieuzasadnionych, opłat za usługi kredytowe [zob. szerzej: Paleczna 2019b] w dniu 15 sierpnia 2015 r. mocą ustawy o zmianie ustawy o nadzorze nad rynkiem finansowym oraz niektórych innych ustaw [Dz.U. 2015, poz. 1357, dalej: ustawa nowelizująca], ustawodawca dokonał między innymi nowelizacji ustawy o kredycie konsumenckim ${ }^{3}$. Wprowadzenie istotnych zmian do ustawy o kredycie konsumenckim, uzasadnione było potrzebą zapewnienia ochrony interesów konsumentów ${ }^{4}-$ kredytobiorców poprzez ograniczenie „kosztowych” i „kosztownych” praktyk kredytodawców. Do ustawy o kredycie konsumenckim dodano: art. 6a, wprowadzający

${ }^{1}$ Kredytodawca w rozumieniu art. 5 pkt 2 ustawy z dnia 12 maja 2011 r.o kredycie konsumenckim [T.j. Dz.U. 2019, poz. 1083], czyli przedsiębiorca w rozumieniu przepisów ustawy z dnia 23 kwietnia 1964 r. - Kodeks cywilny, który w zakresie swojej działalności gospodarczej lub zawodowej, udziela lub daje przyrzeczenie udzielenia konsumentowi kredytu. Kredytodawcą kredytu konsumenckiego jest zatem: bank krajowy, bank zagraniczny, oddział banku zagranicznego, instytucja kredytowa lub oddział instytucji kredytowej w rozumieniu ustawy z dnia 29 sierpnia $1997 \mathrm{r}$. - Prawo bankowe [Dz.U. 2019, poz. 2357], spółdzielcza kasa oszczędnościowo-kredytowa, Krajowa Spółdzielcza Kasa Oszczędnościowo-Kredytowa, instytucja pożyczkowa w rozumieniu art. 5 pkt 2a ustawy z dnia 12 maja 2011 r. o kredycie konsumenckim.

${ }^{2}$ Kredyt konsumencki w rozumieniu art. 3 u.k.k. [T.j. Dz.U. 2019, poz. 1083], czyli umowa o kredyt w wysokości nie większej niż 255550 zł albo równowartość tej kwoty w walucie innej niż waluta polska, który kredytodawca w zakresie swojej działalności udziela lub daje przyrzeczenie udzielenia konsumentowi. Za umowę kredytu konsumenckiego uważa się także umowę pożyczki. Należy również dodać, że umowa pożyczki, której wartość przekracza tysiąc złotych, wymaga zachowania formy dokumentowej.

${ }^{3}$ Przepisami ustawy z dnia 15 sierpnia 2015 r. o zmianie ustawy o nadzorze nad rynkiem finansowym oraz niektórych innych ustaw [Dz.U. 2015, poz. 1357] dokonano nowelizacji ustawy z dnia 12 maja 2011 r. o kredycie konsumenckim [T.j. Dz.U. 2014, poz. 1497].

${ }^{4}$ Konsument w rozumieniu art. $22^{1}$ ustawy z dnia 23 kwietnia 1964 r. - Kodeks cywilny [Dz.U. 2019, poz. 1145], czyli: osoba fizyczna dokonującą z przedsiębiorcą czynności prawnej niezwiązanej bezpośrednio z jej działalnością gospodarczą lub zawodową. 
definicję pozaodsetkowych kosztów kredytu, art. 36a regulujący maksymalną wysokość pozaodsetkowych kosztów kredytu ${ }^{5}$, art. 36b dotyczący zasad obliczania kosztów w przypadku odroczenia spłaty kredytu i art. 36c dotyczący ustalania kosztów kredytu w przypadku udzielenia kolejnych kredytów przed dokonaniem spłaty kredytu. Należy wskazać, że celem wprowadzenia tzw. ustawowych limitów pozaodsetkowych kosztów kredytu konsumenckiego jest ochrona kredytobiorcy konsumenta przed nadmiernymi kosztami kredytu konsumenckiego, jak również ograniczenie praktyk kredytodawców polegających na naliczaniu wysokich kosztów refinansowania kredytu lub wydłużenia terminu jego spłaty ${ }^{6}$. Poprzez wprowadzenie do ustawy o kredycie konsumenckim przepisów regulujących kwestie limitu pozaodsetkowych kosztów kredytu, ustawodawca dąży do ograniczenia przewagi informacyjnej oraz strukturalnej kredytodawców nad konsumentami.

Niestety, mimo obowiązywania tych przepisów, kredytodawcy stosują praktyki, które zmierzają do ich obejścia. Dodatkowo, kredytodawcy wykorzystują oni niewiedzę konsumentów na temat usług kredytowych oraz ich ograniczoną świadomość w zakresie ponoszonych kosztów usługi kredytowej. Bywa tak, że kredytodawcy, będący podmiotami powiązanymi kapitałowo lub osobowo, kreują ,sieci sprzedaży" umów kredytu konsumenckiego. Czerpią wtedy korzyści finansowe z zawartych umów kredytowych, jednocześnie obciążając konsumentów kosztami, często nadmiernymi, w stosunku do świadczonej usługi. Stwierdzenia te stanowią tezę niniejszego opracowania, a podjęte rozważania mają na celu jej udowodnienie.

Przedstawione w opracowaniu zjawisko refinansowania kredytu udzielonego konsumentowi przez różne podmioty powiązane kapitałowo bądź osobowo na mocy decyzji Prezesa Urzędu Ochrony Konkurencji i Konsumentów z dnia 23 września 2019 r. RGD-4/2019, zostało uznane za praktykę naruszającą zbiorowe interesy

${ }^{5}$ Zgodnie z art. 5 pkt 6a u.k.k [T.j. Dz.U. 2019, poz. 1083], pozaodsetkowe koszty kredytu - wszystkie koszty, które konsument ponosi w związku z umową o kredyt konsumencki, z wyłączeniem odsetek.

${ }^{6}$ Ze względu na liczne problemy interpretacyjne ,pozaodsetkowych kosztów kredytu” oraz konieczność ustalenia zgodności przepisów krajowych wprowadzających pojęcie „pozaodsetkowych kosztów kredytu" z przepisami Dyrektywy Parlamentu Europejskiego i Rady 2008/48/WE z dnia 23 kwietnia 2008 r. w sprawie umów o kredyt konsumencki oraz uchylająca dyrektywę Rady 87/102/EWG, Sąd Rejonowy w Siemianowicach Śląskich złożył do Trybunału Sprawiedliwości Unii Europejskiej wniosek o wydanie orzeczenia w trybie prejudycjalnym dotyczący wykładni ww. dyrektywy. Trybunał Sprawiedliwości Unii Europejskiej w Wyroku z dnia 26 marca 2020 r., C-779/18, orzekł, że: „Artykuł 3 lit. g), art. 10 ust. 2 i art. 22 ust. 1 dyrektywy Parlamentu Europejskiego i Rady 2008/48/WE z dnia 23 kwietnia 2008 r. w sprawie umów o kredyt konsumencki oraz uchylającej dyrektywę Rady 87/102/EWG należy interpretować w ten sposób, że nie stoją one na przeszkodzie przepisom krajowym, które ustanawiają metodę obliczania maksymalnej kwoty pozaodsetkowych kosztów kredytu, jakimi można obciążyć konsumenta, pod warunkiem, że przepisy te nie wprowadzają w odniesieniu do tych pozaodsetkowych kosztów kredytu dodatkowych obowiązków informacyjnych ponad te określone w art. 10 ust. 2". 
konsumentów. Jest to jedyna wydana dotychczas ${ }^{7}$ decyzja przez Prezesa Urzędu Ochrony Konkurencji i Konsumentów w tym zakresie. Nie oznacza to jednak, że tego typu praktyka kredytodawców względem konsumentów nadal nie występuje.

W opracowaniu omówiono problem refinansowania kredytu udzielonego konsumentowi przez różne podmioty powiązane kapitałowo lub osobowo, na przykładzie praktyk rynkowych instytucji pożyczkowych, które są kredytodawcami kredytu konsumenckiego, a prowadzą swoją działalność w formie spółki z ograniczoną odpowiedzialnością albo w spółki akcyjnej.

Celem niniejszego opracowania jest wykazanie, że instytucje pożyczkowe stosują praktyki, polegające na refinansowaniu kredytu (pożyczki) udzielonego konsumentowi przez różne podmioty powiązane kapitałowo bądź osobowo i istotnie naruszają przepisy ustawy o kredycie konsumenckim w zakresie stosowania art. 36a $i$ art. 36c u.k.k., co pozwala na uznanie tej praktyki za naruszającą zbiorowe interesy konsumentów.

W opracowaniu wykorzystano materiały źródłowe oraz zastosowano dwie metody badawcze: prawno-dogmatyczną i empiryczną, aby móc zrealizować cel opracowania i udowodnić postawioną tezę.

$\mathrm{Z}$ uwagi na ograniczone ramy opracowania, autorka nie analizuje szczegółowo art. 36a-art. 36c u.k.k.

\section{PRAKTYKA RYNKOWA KREDYTODAWCÓW KREDYTU KONSUMENCKIEGO POLEGAJACCA NA OMINIĘCIU ART. 36A I 36C USTAWY Z DNIA 12 MAJA 2011 R. O KREDYCIE KONSUMENCKIM}

Nieprawidłowością, która uwidoczniła się na przestrzeni kilku ostatnich lat w praktykach rynkowych kredytodawców, zwłaszcza instytucji pożyczkowych ${ }^{8}$, jest obejście przepisów ustawy z dnia 12 maja 2011 r. o kredycie konsumenckim [dalej ustawa o kredycie konsumenckim lub u.k.k.], dotyczących wysokości maksymalnych pozaodsetkowych kosztów kredytu w przypadku udzielenia przez kredytodawcę konsumentowi, który nie dokonał pełnej spłaty kredytu, kolejnych kredytów w okresie 120 dni od dnia wypłaty pierwszego z kredytów ${ }^{9}$. Jest to zatem

${ }^{7}$ Stan na 30 czerwca $2020 \mathrm{r}$.

${ }^{8}$ Instytucja pożyczkowa w rozumieniu art. 5 pkt 2a u.k.k. [T.j. Dz.U. 2019, poz. 1083], czyli kredytodawca inny niż: bank krajowy, bank zagraniczny, oddział banku zagranicznego, instytucja kredytowa lub oddział instytucji kredytowej w rozumieniu ustawy z dnia 29 sierpnia 1997 r. - Prawo bankowe [T.j. Dz.U. 2019, poz. 2357], spółdzielcza kasa oszczędnościowo-kredytowa, Krajowa Spółdzielcza Kasa Oszczędnościowo-Kredytowa; podmiot, którego działalność polega na udzielaniu kredytów konsumenckich w postaci odroczenia zapłaty ceny lub wynagrodzenia na zakup oferowanych przez niego towarów i usług.

${ }_{9} \mathrm{O}$ limitach pozaodsetkowych kosztów kredytu konsumenckiego, jego konstrukcji, podstawach ich obliczenia oraz sposobie jego działania zob. szerzej: Czech 2016: 52-75. Zob. także: Obzejta 2020. 
omijanie limitu pozaodsetkowych kosztów kredytu uregulowanego w art. 36c u.k.k., poprzez sztuczne rozdzielanie kredytów [Czech 2016: 66]. Taka praktyka kredytodawców względem konsumentów określana jest jako refinansowanie kredytu udzielonego przez różne podmioty powiązane kapitałowo lub osobowo ${ }^{10}$.

Praktyka ta polega na współpracy kliku podmiotów (kredytodawców i pośredników kredytowych), które są powiązane ze sobą kapitałowo lub osobowo i de facto obsługują tych samych kredytobiorców konsumentów.

Na potrzeby dalszych rozważań należy wyjaśnić, że podmiotem powiązanym kapitałowo bądź osobowo zgodnie definicją ustawową zawartą w art. $4 \S 1$ ust. 1 pkt. 5 ustawy z dnia 15 września 2000 r. Kodeks spółek handlowych ${ }^{11}$, jest: „spółka kapitałowa, w której inna spółka handlowa albo spółdzielnia dysponuje bezpośrednio lub pośrednio co najmniej $20 \%$ głosów na zgromadzeniu wspólników albo na walnym zgromadzeniu, także jako zastawnik lub użytkownik, albo na podstawie porozumień $\mathrm{z}$ innymi osobami lub która posiada bezpośrednio co najmniej 20\% udziałów albo akcji w innej spółce kapitałowej”.

Powiązania te są szczególnie widoczne między instytucjami pożyczkowymi i pośrednikami kredytowymi. Mechanizm tego działania w uproszczony sposób wygląda następująco: konsument, korzystając z usług pośrednika kredytowego, zawiera umowę kredytu konsumenckiego z pierwotnym kredytodawcą (instytucja pożyczkowa), w przypadku problemów z terminową spłatą zobowiązania kredytobiorca konsument decyduje się skorzystać z refinansowania kredytu lub przedłużyć termin spłaty „zagrożonego” kredytu. W rzeczywistości jednak pierwotny kredytodawca (instytucja pożyczkowa) nie oferuje możliwości odroczenia spłaty kredytu. Wtedy to kredytobiorca konsument, korzystając $\mathrm{z}$ usług pośrednika kredytowego, zawiera umowę kredytu refinansującego $\mathrm{z}$ innym kredytodawcą (także instytucją pożyczkową), który jest powiązany kapitałowo lub osobowo z pierwotnym kredytodawcą i pośrednikiem kredytowym. Z analiz Rzecznika Finansowego przeprowadzonych na podstawie skarg konsumentów [Raport Rzecznika Finansowego, 2018: 6], wynika, że głównym albo jedynym udziałowcem kredytodawców, a niekiedy także pośrednika kredytowego, bardzo często jest ta sama spółka kapitałowa. Bywa również tak, że prezesem zarządu instytucji pożyczkowej (kredytodawcy) i pośrednika jest ta sama osoba [Raport Rzecznika Finansowego 2018: 6]. Wobec tego należy wskazać, że: „Dochodzi zatem do wykreowania sieci sprzedaży umów kredytu konsumenckiego złożonej z kilku kredytodawców i pośrednika będącego ogniwem łączącym konsumenta z kredytodawcami” [Raport Rzecznika Finansowego 2018: 6].

W sytuacji przedstawionej powyżej, każdy z kredytodawców udzielający kredytu refinansowego zawiera $\mathrm{z}$ kredytobiorcą konsumentem odrębną umowę

${ }^{10}$ Pojęciem tym posługują się polskie instytucje ochrony konsumenta na rynku usług finansowych, czyli Urząd Ochrony Konkurencji i Konsumenów oraz Rzecznik Finansowy.

${ }^{11}$ Ustawa z dnia 15 września 2000 r. Kodeks spółek handlowych [T.j. Dz.U. 2020, poz. 1526]. 
pożyczki (jest to de facto umowa kredytu konsumenckiego) ${ }^{12}$. Dochodzi zatem jedynie do formalnej zmiany kredytodawcy. Pozwala to na dalsze obciążanie konsumentów kosztami opłat za udzielenie kolejnej pożyczki (rozumianej jako kredyt konsumencki) (kredytu) [zob. także: Koćwin 2019; Rutkowska-Tomaszewska 2016: 28-47; Paleczna 2018: 115-134, Paleczna 2020] ${ }^{13}$. Ze względu na brak ograniczeń ustawowych, dotyczących limitu zawieranych umów kredytowych przez konsumentów, liczba umów kredytów refinansujących może być bardzo duża [por. Czech 2016: 66-67].

W rezultacie kredytobiorca konsument każdorazowo jest obciążony kosztami zawarcia umowy kredytowej, w szczególności opłatami i prowizjami, które ze względu na brak zastosowania art. 36c u.k.k., są ustalane na wysokim poziomie [zob. szerzej Dąbrowska-Antoniak 2019: 353]. Potwierdzają to analizy Rzecznika Finansowego, który wykazał, że opłaty naliczane konsumentom z tytułu udzielenia kredytu refinansującego: ,były nawet o ponad $90 \%$ wyższe, niż byłoby to dopuszczalne w przypadku odroczenia spłaty pierwotnego kredytu u tego samego kredytodawcy z zastosowaniem limitu pozaodsetkowych kosztów kredytu" [Raport Rzecznika Finansowego 2018: 8]. Opisana praktyka kredytodawców jest zatem obejściem przepisów ustawy o kredycie konsumenckim w zakresie limitów pozaodsetkowych kosztów, czyli art. 36a i art. 36c u.k.k.

\section{PRAKTYKA NARUSZAJĄCA ZBIOROWE INTERESY KONSUMENTÓW - UWAGI OGÓLNE}

Działanie kredytodawcy, polegające na refinansowaniu kredytu udzielonego konsumentowi przez różne podmioty powiązane kapitałowo bądź osobowo, niewątpliwie jest naruszeniem przepisów ustawy o kredycie konsumenckim w zakresie limitów pozaodsetkowych kosztów kredytu. Takie działanie można również uznać za zakazaną praktykę naruszającą zbiorowe interesy konsumentów zgodnie z art. 24 ust. 1 i 2 ustawy z dnia 16 lutego 2007 r. o ochronie konkurencji i konsumentów [T.j. Dz.U. 2020, poz. 1076, dalej: u.o.k.i.k.].

W tym miejscu, dla zrozumienia dalszych rozważań, należy wskazać, czym jest zakazana praktyka naruszająca zbiorowe interesy konsumentów, i jakie muszą zostać spełnione przesłanki, aby zachowanie przedsiębiorcy, w ninijeszym opracowaniu kredytodawcy, mogło zostać uznane za taką praktykę [zob. szerzej: Wesołowska 2014: 90 i n.]. Zgodnie z art. 24 ust. 2 u.o.k.i.k., przez praktykę naruszającą zbiorowe interesy konsumentów rozumie się godzące w nie, sprzeczne

12 Ponownie należy zaznaczyć, że na gruncie przepisów ustawy o kredycie konsumenckim, umowa pożyczki uważana jest za umowę o kredyt konsumencki. O umowach mieszczących się w ramach umowy kredytu konsumenckiego zob. szerzej: Grochowski 2019, Art. 3.

${ }^{13} \mathrm{Na}$ rynku niebankowych kredytów konsumenckich dochodzi do wielu nieprawidłowości w zakresie odpłatności za usługę kredytową. Jest to przede wszystkim manipulowanie informacją odnośnie kosztów kredytu. 
z prawem lub dobrymi obyczajami zachowanie przedsiębiorcy [zob. szerzej: Rutkowska-Tomaszewska 2019: 25-28 oraz powoływana tam literatura; Rutkowska-Tomaszewska 2014b: 67-94; Sieradzka 2014: 575; Wesołowska 2014: 90 i n.]. Przepis ten uzupełniony jest przykładowym katalogiem praktyk, naruszających zbiorowe interesy konsumentów, to jest:

- naruszanie obowiązku udzielania konsumentom rzetelnej, prawdziwej i pełnej informacji,

- nieuczciwe praktyki rynkowe lub czyny nieuczciwej konkurencji,

- proponowanie konsumentom nabycia usług finansowych, które nie odpowiadają potrzebom tych konsumentów, ustalonym z uwzględnieniem dostępnych przedsiębiorcy informacji $\mathrm{w}$ zakresie cech tych konsumentów lub proponowanie nabycia tych usług w sposób nieadekwatny do ich charakteru - misselling [zob. szerzej: Nizioł 2019; Szakun 2019: 59-64; Rutkowska-Tomaszewska 2019: 28-33; Sroczyński 2016: 26-31; Paleczna 2019a: 50-64; Jurkowska-Zeidler 2016: 198-200].

Ustawowy zakaz stosowania przez przedsiębiorców, więc także kredytodawców, praktyk naruszających zbiorowe interesy konsumentów nie ogranicza się jedynie do praktyk wymienionych przez ustawodawcę. Praktyką naruszającą zbiorowe interesy konsumentów będzie każde zachowanie kredytodawcy sprzeczne z prawem lub dobrymi obyczajami, które godzi w zbiorowy interes konsumentów.

Praktyka rynkowa przedsiębiorcy (kredytodawcy), aby mogła zostać uznana za naruszającą zbiorowe interesy konsumentów, musi dotyczyć nieograniczonego kręgu adresatów, którzy posiadają status konsumentów. Wskazuje się również, że praktyki te muszą być kierowane zarówno do obecnych, przyszłych, a nawet potencjalnych konsumentów [Sieradzka 2014: 587]. Warto również dodać, że naruszenie zbiorowego interesu konsumentów może mieć miejsce wtedy, gdy daną praktyką przedsiębiorcy może być dotknięty każdy konsument $\mathrm{w}$ analogicznych okolicznościach [por. Wyrok Sądu Okręgowego w Warszawie Sąd Ochrony Konkurencji i Konsumentów z dnia 13 stycznia 2009 r., sygn. akt XVII Ama 26/08].

Co ciekawe, choć ustawodawca posługuje się pojęciem ,zbiorowe interesy konsumentów", to jednak w ustawie o ochronie konkurencji i konsumentów nie ma definicji tego pojęcia. Ustawodawca w art. 24 ust 3 u.o.k.i.k., podkreślił, że nie jest zbiorowym interesem konsumentów suma indywidualnych interesów konsumentów. Wobec powyższego, należy zwrócić uwagę także na stanowisko Urzędu Ochrony Konkurencji i Konsumentów, zgodnie z którym jest to interes znacznej grupy lub wszystkich konsumentów [Decyzja Prezesa UOKiK z dnia 23 września 2019 r. RGD-4/2019: 27]. Z decyzji wydanych przez Prezesa UOKiK można również wnioskować, że przez pojęcie zbiorowego interesu należy rozumieć konsumentów, do których skierowane jest działanie przedsiębiorcy. Warto zaznaczyć, że są to działania skierowane do oznaczonych (zindywidualizowanych), jednakże dostatecznie licznych konsumentów, których łączą pewne 
wspólne cechy. Warto również wskazać stanowisko Prezesa UOKiK, który w Decyzji Prezesa UOKiK z dnia 19 czerwca 2020 r. nr RWR 4/2020, stwierdził, że „poszkodowana zostaje pewna grupa konsumentów, niebędąca jedynie - z punktu widzenia przedsiębiorcy stosującego daną praktykę - zbiorowością przypadkowych jednostek, lecz stanowiącą określoną i odrębną kategorię konsumentów, reprezentującą w znacznym stopniu wspólne interesy" [Decyzja Prezesa UOKiK z dnia 19 czerwca 2020 r. nr RWR 4/2020: 16]. Mając na względzie powyższe, można zatem stwierdzić, że przedstawione definicje łączy wspólna cecha - abstrakcyjność konsumentów [zob. szerzej: Sieradzka 2008: 105]. Dlatego też: „rozumienie zbiorowego interesu konsumentów nie może zostać ograniczone zarówno do prostej całości (sumy) interesów indywidualnych, jak i ich wielokrotności" [Sieradzka 2008: 105]. Podsumowując, należy uznać, że jest to zatem taki interes, który odpowiada zbiorowi konsumentów.

Natomiast przez „godzenie w zbiorowe interesy konsumentów” należy rozumieć: ,narażenie na uszczerbek interesów znacznej grupy lub wszystkich konsumentów" [Decyzja Prezesa UOKiK z dnia 23 września 2019 r. RGD-4/2019: 27]. Zachowanie takie wywołuje jednocześnie niekorzystne następstwa w stosunku do każdego z konsumentów. Dodatkowo, aby zachowanie przedsiębiorcy mogło zostać zakwalifikowane jako naruszenie zakazu, o którym mowa w art. 24 ust. 1 u.o.k.i.k., powinno być powtarzalne.

Ustawodawca nie wskazał, jakie konkretnie zachowanie przedsiębiorcy stanowi praktykę naruszającą zbiorowe interesy konsumentów. Oznacza to zatem, że taką praktyką jest również zaniechanie przedsiębiorcy [Rutkowska-Tomaszewska 2014b: 74; Sieradzka 2014: 578-579]. Dla stwierdzenia przez Prezesa UO$\mathrm{KiK}$, że przedsiębiorca (kredytodawca) stosuje zakazaną praktykę naruszającą zbiorowe interesy konsumentów, musi zostać wykazane, że istnieje związek pomiędzy interesem konsumentów a naruszoną normą prawną (por. Wyrok Sądu Okręgowego w Warszawie - XVII Wydział Gospodarczy z dnia 23 maja 2011 r., sygn. akt XVII AmA 212/09].

Mając na uwadze powyższe, można zatem stwierdzić, że praktyką naruszającą zbiorowe interesy konsumentów jest działanie przedsiębiorcy, które cechuje powtarzalność w stosunku do indywidualnych konsumentów wchodzących w skład grupy konsumentów. Warto dodać, że przedsiębiorca działa w taki sposób, że potencjalnie adresatem jego działania może być każdy konsument, zarówno obecny jak i potencjalny [por. Wyrok Sądu Najwyższego z dnia 10 kwietnia 2008 r., III SK 27/07, OSNP 2009, nr 13-14, poz. 188].

W myśl art. 25 u.o.k.i.k., ochrona zbiorowych interesów konsumentów przewidziana w ustawie o ochronie konkurencji i konsumentów, nie wyłącza ochrony wynikającej z innych ustaw. Jest to ustawowe rozszerzenie ochrony zbiorowych interesów konsumentów. Dlatego też konsumenci mogą korzystać z ochrony prawnej, która przewidziana jest m.in. na podstawie przepisów ustawy z dnia 
23 sierpnia 2007 r. o przeciwdziałaniu nieuczciwym praktykom rynkowym [T.j. Dz.U. 2017, poz. 2070].

Jeżeli przeprowadzone postępowanie wykaże, że przedsiębiorca (kredytodawca) naruszył zakaz określony w art. 24 u.o.k.i.k., to Prezes Urzędu Ochrony Konkurencji i Konsumentów [dalej: Prezes UOKiK] na podstawie art. 26 ust. 1 u.o.k.i.k., wydaje decyzję o uznaniu praktyki za naruszającą zbiorowe interesy konsumentów i nakazuje zaniechanie jej stosowania. Prezes UOKiK, wydając decyzję na podstawie art. 26 ust. 1 u.o.k.i.k., może skorzystać z uprawnienia zawartego w art. 26 ust. 2 u.o.k.i.k., czyli: określić środki usunięcia trwających skutków naruszenia zbiorowych interesów konsumentów w celu zapewnienia wykonania nakazu, w szczególności zobowiązać przedsiębiorcę do złożenia jednokrotnego lub wielokrotnego oświadczenia o treści i w formie określonej w decyzji. Należy jednak zastrzec, że środki te powinny być jednak proporcjonalne do wagi i rodzaju naruszenia oraz konieczne do usunięcia jego skutków. Prezes UOKiK na podstawie art. 26 ust. 3 u.o.k.i.k., może nakazać publikację decyzji w całości lub w części, z zaznaczeniem, czy decyzja ta jest prawomocna, w określonej w niej formie, na koszt przedsiębiorcy. Należy jednak podkreślić, że są to działania o charakterze uznaniowym. Oznacza to, że ustawodawca przyznał organowi możliwość wyboru skorzystania z tych uprawnień [zob. szerzej: Sieradzka 2016, LEX/el; Jurkowska-Gomulka 2016, LEX/el).

Należy zatem jednoznacznie stwierdzić, że ochrona konsumentów sprawowana przez Prezesa UOKiK nie dotyczy indywidualnego interesu konsumenta [por. Rutkowska-Tomaszewska 2014b: 71], a interesów konsumentów, których działania przedsiębiorcy bezpośrednio dotyczą, i których sytuacja jest w tym zakresie podobna [Decyzja Prezesa UOKiK z dnia 23 września 2019 r. RGD-4/2019: 10].

\section{DECYZJA PREZESA URZĘDU OCHRONY KONKURENCJI I KONSUMENTÓW Z DNIA 23 WRZEŚNIA 2019 R. RGD-4/2019 UZNAJĄCA PRAKTYKĘ "REFINANSOWANIA KREDYTU” ZA NARUSZAJĄCA ZBIOROWE INTERESY KONSUMENTÓW}

Przedstawiona w poprzedniej części opracowania praktyka, polegająca na refinansowaniu kredytu udzielonego konsumentowi przez różne podmioty powiązane kapitałowo bądź osobowo i będąca zarazem próbą obejścia przepisów limitów pozaodsetkowych kosztów kredytów, była przedmiotem postępowania w sprawie praktyk naruszających zbiorowe interesy konsumentów prowadzonego przez Urząd Ochrony Konkurencji Konsumentów [dalej: UOKiK] w latach 2018-2019.

Przedmiotem prowadzonego postępowania przez UOKiK były działania podmiotów z grupy Złotówka, tj. Spółka Złotówka Bis, Złotówka Duo oraz Złotówka Three [dalej: przedsiębiorcy $\mathrm{z}$ grupy Złotówka]. Ustalono także, że wszyscy 
przedsiębiorcy z grupy Złotówka mieli ten sam adres siedziby - Bydgoszcz - i funkcjonowali w ramach jednej grupy kapitałowej [Decyzja Prezesa UOKiK z dnia 23 września 2019 r. RGD-4/2019: 10]. Przedsiębiorcy ci prowadzili swoją działalność głównie na terenie województwa pomorskiego oraz kujawsko-pomorskiego. W ramach tego postępowania UOKiK stwierdził, że przedsiębiorcy z grupy Złotówka oferowali konsumentom krótkoterminowe pożyczki , czyli tzw. „chwilówki”" ${ }^{14}$. W trakcie postępowania ujawiono również, że przedsiębiorcy z grupy Złotówka stosowali wzorce umowne, których tresć była identyczna. Odróżniała je jedynie nazwa i oznaczenie konkretnego kredytodawcy.

Prezes UOKiK, po uzyskaniu zawiadomienia oraz skarg konsumenckich, wszczął postępowanie wyjaśniające w sprawie ustalenia, czy przy oferowaniu i udzielaniu konsumentom pożyczek przez podmioty z grupy Złotówka, doszło do naruszenia przepisów art. 24 ust. 1 i 2 u.o.k.i.k., a także innych ustaw chroniących prawa konsumentów.

Analiza materiału dowodowego zgromadzonego w toku postępowania wyjaśniającego wykazała istnienie podstaw do postawienia przedsiębiorcom z grupy Złotówka zarzutu naruszenia zakazu, o którym mowa w przepisie art. 24 ust. 1 u.o.k.i.k. W dniu 22 maja 2018 r. Prezes UOKiK, wszczął postępowanie w sprawie praktyk naruszających zbiorowe interesy konsumentów przeciwko przedsiębiorcom z grupy Złotówka.

Podstawowym zarzutem postawionym przedsiębiorcom z grupy Złotówka była praktyka określona w art. 24 ust. 1 i 2 u.o.k.i.k., polegająca na udzielaniu przez tych przedsiębiorców, w okresie 120 dni od dnia wypłaty pierwszej pożyczki, kolejnych pożyczek gotówkowych z naruszeniem art. 36a oraz art. 36c u.k.k. W decyzji Prezesa UOKiK z dnia 23 września 2019 r. RGD-4/2019 [dalej: decyzja RGD-4/2019], Stwierdzono, że w ustalonym stanie faktycznym ${ }^{15}$ przedsiębiorcy z grupy Złotówka dopuścili się bezprawnych działań, których celem było ominięcie przepisów art. 36a i art. 36c u.k.k.

Mechanizm działania przedsiębiorców z grupy Złotówka został szczegółowo przedstawiony w uzasadnieniu decyzji RGD-4/2019. Udowodniono, że przedsiębiorcy zawierali umowy pożyczki z konsumentami w kwotach nieprzekraczających zazwyczaj wysokości 1 tys. zł. W przypadku, gdy konsument nie miał możliwości terminowej spłaty zobowiązania, zawierana była nowa umowa. W rzeczywistości jednak na „dokumentach przedłużających” umowę [Decyzja Prezesa UOKiK z dnia 23 września 2019 r. RGD-4/2019: 14], widniały różne nazwy przedsiębiorców, tj.

${ }^{14} \mathrm{~W}$ trakcie podjętych działań Prezes UOKiK ustalił, że przedsiębiorcy z grupy Złotówka udzielali konsumentom kredytów konsumenckich na okres jednego miesiąca, a ich wysokość zawierała się w przedziale od 400 zł do 1000 zł. Decyzja Prezesa UOKiK z dnia 23 września 2019 r. RGD-4/2019: 6.

${ }^{15}$ Potwierdzeniem tych działań był zebrany materiał dowodowy - opisane stany faktyczne wybranych klientów. 
Złotówka Three, Złotówka Bis, Złotówka Duo. Potwierdzeniem tych działań były oświadczenia konsumentów korzystających z usług przedsiębiorców z grupy Złotówka. Na podstawie analiz tych oświadczeń, Prezes UOKiK w decyzji RGD4/2019 stwierdził, że współpraca przedsiębiorców była celowa i miała doprowadzić do „stałego i nieograniczonego pobierania środków tytułem opłaty rzekomych kosztów z tytułu fikcyjnie udzielanych, kolejnych pożyczek" [Decyzja Prezesa UOKiK z dnia 23 września 2019 r. RGD-4/2019: 14].

Postępowanie wyjaśniające prowadzone przez UOKiK wykazało również, że model działania przedsiębiorców z grupy Złotówka, w przypadku refinansowania kredytu, zakładał dokonywanie przez konsumentów stałych, comiesięcznych (wysokich) spłat. Warto zaznaczyć, że konsumenci nie otrzymywali środków z tytułu nowozawartej umowy, a także rozliczeń wskazujących, że doszło do faktycznego przeznaczenia środków na spłatę kredytów.

Prezes UOKiK w decyzji RGD-4/2019, jednoznacznie stwierdził, że mechanizm działania przedsiębiorców wchodzących w skład grupy Złotówka polegał na tzw. „rotacyjnym” udzielaniu pożyczek, którego celem było ustalanie pozaodsetkowych kosztów kredytu na poziomie wyższym, niż w sytuacji, gdyby każda kolejna umowa refinansowania kredytu była zawarta osobno, przy jednoczesnym przestrzeganiu limitów określonych $\mathrm{w}$ art. 36c u.k.k.

Ten „,rotacyjny” mechanizm udzielania pożyczek umożliwiał przedsiębiorcom z grupy Złotówka obejście art. 36a i art. 36c u.k.k. Dodatkowo, sposób działania tych przedsiębiorców powodował, że konsumenci ,,wpadali w błędne koło długu" [por. Rutkowska-Tomaszewska 2018: 115-136; Rutkowska-Tomaszewska 2014a: 273-296; Szpringer 2009: 79]. Konsumenci, mimo regularnych, comiesięcznych, wpłat nie mogli faktycznie spłacić zadłużenia.

$\mathrm{W}$ tym miejscu warto przytoczyć stanowisko przedsiębiorców z grupy Złotówka w sprawie stawianych im zarzutów dotyczących rolowania pożyczek: „Współpraca pomiędzy DUO, BIS i THREE była odpowiedzią na potrzeby klientów, którymi zazwyczaj są osoby nie posiadające zdolności kredytowej i które nie otrzymają pożyczki z innego źródła, są to osoby - jak ujęli to ww. przedsiębiorcy - wykluczone z rynku kredytów, potrzebujące środków na zaspokojenie swoich potrzeb życiowych/niezbędnych do egzystencji. Jak wskazały Spółki, udzielane przez nie pożyczki są (...) niejednokrotnie jedynym ratunkiem dla tych ludzi" [Decyzja Prezesa UOKiK z dnia 23 września 2019 r. RGD-4/2019: 15]. Mając na względzie zaprezentowane stanowisko przedsiębiorców oraz faktyczny sposób ich działania, niewątpliwie należy stwierdzić, że praktyki rynkowe tych przedsiębiorców były sprzeczne $z$ dobrymi obyczajami i nieetyczne. Były one także niezgodne z postulowaną ideą odpowiedzialnego pożyczania i kredytowania [zob. także: Rutkowska-Tomaszewska 2018: 115-136; Rutkowska-Tomaszewska i Paleczna 2018: 38-52), co skutkowało pogorszeniem sytuacji finansowej konsumentów. 
Prezes UOKiK w decyzji RGD-4/2019 potwierdził, że przedsiębiorcy wchodzący w skład grupy Złotówka, dopuścili się bezprawnych działań, związanych z naruszeniem przepisów ustawy o kredycie konsumenckim - art. 36a i art. 36c, co w konsekwencji wypełniło przesłanki art. 24 ust. 2 u.o.k.i.k.

Na podstawie art. 106 ust. 1 pkt 4 u.o.k.i.k., w związku z art. 106 ust. 6 u.o.k.i.k. Prezes UOKiK nałożył na przedsiębiorców z grupy Złotówka karę pieniężną w łącznej wysokości 24500 zł (Złotówka Bis 16500 zł, Złotówka Duo 3000 zł, Złotówka Three 5400 zł), w związku ze stosowaniem praktyki naruszającej zbiorowe interesy konsumentów, polegającej na udzielaniu przez ww. przedsiębiorców, w okresie 120 dni od dnia wypłaty pierwszej pożyczki, kolejnych pożyczek gotówkowych, z naruszeniem przepisów art. 36a oraz art. 36c u.k.k. Warto jednak zaznaczyć, że zgodnie z art. 106 ust. 1 pkt 4 u.o.k.i.k., Prezes UOKiK może nałożyć na przedsiębiorcę, w drodze decyzji, karę pieniężną w wysokości nie większej niż $10 \%$ obrotu osiągniętego w roku obrotowym poprzedzającym rok nałożenia kary, jeżeli przedsiębiorca ten, choćby nieumyślnie dopuścił się naruszenia zakazu określonego w art. 24 u.o.k.i.k. [zob. szerzej: Król-Bogomilska 2014: 1310-1314, 1326]. Oznacza to, że kara pieniężna za naruszenie zakazu stosowania praktyk naruszających zbiorowe interesy konsumentów ma charakter fakultatywny. O nałożeniu kary pieniężnej, w ramach uznania administracyjnego, decyduje Prezes UOKiK. W sprawie przedsiębiorców z grupy Złotówka, Prezes UOKiK przyjął zasadność nałożenia kary pieniężnej.

\section{PODSUMOWANIE}

Opisana w niniejszym opracowaniu praktyka, polegająca na refinansowaniu kredytu udzielonego konsumentowi przez różne podmioty powiązane kapitałowo bądź osobowo, stanowi stwierdzony rodzaj nieprawidłowości na rynku kredytów konsumenckich w Polsce. Kredytodawcy, którzy są odpowiednio powiązani kapitałowo lub osobowo, wykorzystują możliwości interpretacyjne obowiązujących przepisów dla realizacji modeli biznesowych i sprzedażowych.

Praktyka rynkowa kredytodawców, polegająca na refinansowaniu kredytu udzielonego konsumentowi przez różne podmioty powiązane kapitałowo, niewątpliwie ma na celu osiąganie coraz wyższych zysków z prowadzonej działalności. Dla kredytodawcy taki sposób działania jest bardziej opłacalny niż naliczanie odsetek za nieterminową spłatę zobowiązania. Dochodzi bowiem do zawarcia nowej umowy kredytowej z innym (konkretnym) kredytodawcą, przez co konsument zobowiązany jest do uiszczenia opłaty $\mathrm{w}$ związku $\mathrm{z}$ zawieraną umową (umową pożyczki). W rezultacie, kredytobiorca konsument ponosi wyższy koszt z tytułu opłat niż koszt odsetek za zaległości w spłacie.

Należy zatem wskazać, że taki sposób działania kredytodawcy słusznie został uznany przez Prezesa UOKiK za praktykę naruszającą zbiorowe interesy 
konsumentów. Niezaprzeczalnie jest to działanie niezgodne z przepisami obowiązującego prawa, a nade wszystko sprzeczne z dobrymi obyczajami. Jest to więc działanie przedsiębiorcy, które zagraża nie tylko indywidualnym konsumentom, ale stanowi wyraźne zagrożenie dla szerszego grona konsumentów. Działania te mogą wywoływać na rynku usług kredytowych także inne niekorzystne zjawiska, jak chociażby nadmierne zadłużanie się konsumentów, a także zakłócić jego prawidłowe funkcjonowanie.

Niewątpliwie tego typu praktyka rynkowa w sposób istotny zniekształca zachowanie rynkowe przeciętego konsumenta. Dochodzi bowiem do sytuacji, w której kredytobiorca konsument, nie będąc świadomy ryzyka, angażuje się w kolejną usługę kredytową, ponosząc coraz wyższe koszty i jednocześnie „wpada w pułapkę długu”.

Występowanie tego typu praktyki w działaniach kredytodawców i uznanie jej za praktykę naruszającą zbiorowe interesy konsumentów potwierdza konieczność ochrony konsumentów oraz ich interesów ekonomicznych. Istotne jest zatem, aby organy $\mathrm{i}$ instytucje ochrony konsumenta na rynku finansowym ograniczały działania kredytodawców, które są wbrew intencji art. 36a i art. 36c u.k.k., jak również inne, niezgodne z prawem zachowania kredytodawców.

Należy również wskazać, że wobec problemu refinansowania kredytu udzielonego konsumentowi przez różne podmioty powiązane kapitałowo bądź osobowo, ale także pozostałych nieprawidłowości na rynku kredytów konsumenckich, nie pozostaje obojętny polski ustawodawca. W lipcu 2019 r. do Sejmu wpłynął Rządowy projekt ustawy o zmianie niektórych ustaw w celu przeciwdziałania lichwie ${ }^{16}$. Projekt ten ma na celu podjęcie kompleksowych i skoordynowanych działań na gruncie prawa karnego, jak i poprzez ingerencję w stosunki cywilno-prawne, ukierunkowanych na zlikwidowanie patologii udzielania pożyczek o charakterze lichwiarskim. Podjęcie interwencji przez polskiego ustawodawcę niewątpliwie wpłynie na ograniczenie stosowania tego rodzaju praktyki (refinansowania) przez instytucje pożyczkowe, jak i pozostałych kredytodawców.

Podsumowując rozważania podjęte $\mathrm{w}$ niniejszym opracowaniu de lege ferenda należy postulować wprowadzenie do ustawy z dnia 12 maja 2011 r. o kredycie konsumenckim definicji legalnej kredytodawców powiązanych kapitałowo lub osobowo oraz rozszerzenie treści przepisu art. 36 u.k.k., o tego rodzaju kredytodawców. Pozwoli to ograniczyć, a nawet wyeliminować, praktykę kredytodawców przedstawioną $\mathrm{w} \mathrm{w}$ opracowaniu.

Ponadto należałoby się zastanowić nad objęciem sektora instytucji pożyczkowych całkowitym nadzorem Komisji Nadzoru Finansowego dla zachowania bezpieczeństwa finansowego konsumentów kredytobiorców, jak i całego rynku konsumenckich usług kredytowych.

${ }^{16}$ Rządowy projekt ustawy o zmianie niektórych ustaw w celu przeciwdziałania lichwie, Druk sejmowy 3600 dostępny na: https://www.sejm.gov.pl/Sejm8.nsf/PrzebiegProc.xsp?nr=3600 [dostęp 9.09.2020]. 


\section{BIBLIOGRAFIA}

Czech T., 2016, Limit pozaodstekowych kosztów kredytu konsumenckiego, „Monitor Prawa Bankowego", nr 2.

Dąbrowska-Antoniak I., 2019, Przykładowe problemy klientów firm pożyczkowych, [w:] Raport Doradczego Komitetu Naukowego - Nieprawidtowości na rynku finansowym a ochrona konsumenta, A. Jurkowska-Zeidler, J. Monkiewicz, E. Rutkowska-Tomaszewska, T. Bednarczyk, A. Sopoćko (red.), Rzecznik Finansowy, Warszawa, https://rf.gov.pl/pdf/DKN_Raport_nieprawidlowosci_wrzesien2019.pdf [dostęp 22.06.2020].

Decyzja Prezesa Urzędu Ochrony Konkurencji i Konsumentów dnia 19 czerwca 2020 r. nr RWR $4 / 2020$

Decyzja Prezesa Urzędu Ochrony Konkurencji i Konsumentów z dnia 23 września 2019 r. RGD$-4 / 2019$.

Dyrektywa Parlamentu Europejskiego i Rady 2008/48/WE z dnia 23 kwietnia 2008 r. w sprawie umów o kredyt konsumencki oraz uchylająca dyrektywę Rady 87/102/EWG, Dz.Urz. UE L 133/66 z dnia 12 maja $2008 \mathrm{r}$.

Grochowski M., 2019, Art. 3 [Umowa o kredyt konsumencki], [w:] K. Osajda (red.), Ustawa o kredycie konsumenckim. Komentarz, Legalis.

Jurkowska-Gomulka A., 2016, Art. 26 [Decyzje Prezesa Urzędu], [w:] M. Namysłowska, A. Piszcz (red.), Ustawa o ochronie konkurencji i konsumentów. Komentarz, Legalis.

Jurkowska-Zeidler A., 2016, Konsekwencje zmian w systemie ochrony konsumenta ustug finansowych, „Gdańskie Studia Prawnicze”, Tom XXXVI, nr 2.

Koćwin J., 2019, Koszty pożyczek zaciaganych $w$ instytucjach parabankowych online - stosowane optaty, „Przegląd Ustawodastwa Gospodarczego”, Tom LXXII , nr 9(855).

Król-Bogomiska M., 2014, Wprowadzenie oraz Nakładanie kar pieniężnych, [w:] T. Skoczny (red.), Ustawa o ochronie konkurencji i konsumentów, C.H. Beck, Warszawa.

Nizioł K., 2019, Misselling uslug finansowych, Wydawnictwo Naukowe Uniwersytetu Szczecińskiego, Szczecin.

Obzejta Ł., 2020, Koszty pozaodsetkowe zwiąane z kredytem konsumenckim, LEX/el.

Paleczna M., 2018, Koszty usług kredytowych świadczonych przez niebankowe instytucje pożyczkowe, [W:] A. Ćwiąkała-Małys, M. Karpińska (red.), Prawno-finansowe systemy funkcjonowania wybranych jednostek organizacyjnych, Uniwersytet Wrocławski, E-Wydawnictwo. Prawnicza i Ekonomiczna Biblioteka Cyfrowa. Wydział Prawa, Administracji i Ekonomii, Wrocław.

Paleczna M., 2019a, Misselling na rynku niebankowych kredytów konsumenckich w świetle aktualnych problemów rynkowych, ,internetowy Kwartalnik Antymonopolowy i Regulacyjny”, nr 8.

Paleczna M., 2019b, Nieprawidłowości na rynku kredytów konsumenckich, [w:] Raport Doradczego Komitetu Naukowego - Nieprawidłowości na rynku finansowym a ochrona konsumenta, A. Jurkowska-Zeidler, J. Monkiewicz, E. Rutkowska-Tomaszewska, T. Bednarczyk, A. Sopoćko (red.), Rzecznik Finansowy, Warszawa, https://rf.gov.pl/pdf/DKN_Raport_nieprawidlowosci_wrzesien2019.pdf [dostęp 22.06.2020].

Paleczna M., 2020, Nieprawidłowości na rynku kredytów konsumenckich - analiza wybranych problemów, [w:] A. Jurkowska-Zeidler, E. Rutkowska-Tomaszewska, A. Wiktorow, J. Monkiewicz (red.), Manipulacje i oszustwa na rynku finansowym. Perspektywa konsumenta. Wykrywanie, przeciwdziałanie, zapobieganie, Wydawnictwo PWN, Warszawa.

Raport Doradczego Komitetu Naukowego - Nieprawidlowości na rynku finansowym a ochrona konsumenta, 2019, A. Jurkowska-Zeidler, J. Monkiewicz, E. Rutkowska-Tomaszewska, T. Bednarczyk, A. Sopoćko (red.), Rzecznik Finansowy, Warszawa, https://rf.gov.pl/pdf/DKN_Raport_nieprawidlowosci_wrzesien2019.pdf [dostęp 22.06.2020]. 
Raport Rzecznika Finansowego - Kredyty konsumenckie, Bieżace problemy 2018 r., 2018, https://rf.gov.pl/wp-content/uploads/2020/05/Kredyty_konsumenckie_raport_2018.pdf [dostęp 22.06.2020].

Rutkowska-Tomaszewska E., 2014a, Ochrona prawna kredytobiorcy - konsumenta $w$ świetle najnowszych projektowanych regulacji prawnych, [w:] M. Ganczar, E. Sługocka-Krupa (red.), Ochrona konsumentów i jej współczesne wyzwania, Katolicki Uniwersytet Lubelski Jana Pawła II, Lublin.

Rutkowska-Tomaszewska E., 2014b, Praktyki naruszajace zbiorowe interesy konsumentów na rynku usług finansowych ze szczególnym uwzględnieniem rynku ustug bankowych na przykładzie wybranych najnowszych decyzji Prezesa UOKiK, ,internetowy Kwartalnik Antymonopolowy i Regulacyjny", nr 3.

Rutkowska-Tomaszewska E., 2016, Ustugi finansowe - dobrodziejstwo i (czy) zagrożenie dla konsumentów? Czy ochrona konsmenta ustug finansowych jest obecnie efektywna i wystarczajaca?, [w:] M. Jagielska, E. Sługocka-Krupa, K. Podgórski (red.), Ochrona konsumenta na rynku ustug, C.H. Beck, Warszawa.

Rutkowska-Tomaszewska E., 2018, Idea odpowiedzialnego pożyczania na rynku niebankowych kredytów konsumenckich w Polsce, [w:] A. Ćwiąkała- Małys, M. Karpińska (red.), Wyzwania wspótczesnych finansów: wybrane problemy, Uniwersytet Wrocławski. E-Wydawnictwo. Prawnicza i Ekonomiczna Biblioteka Cyfrowa. Wydział Prawa, Administracji i Ekonomii, Wrocław.

Rutkowska-Tomaszewska E., 2019, Nadużycia na rynku ushug finansowych wobec konsumentów: ujęcie ogólne i przeglądowe, [w:] Raport Doradczego Komitetu Naukowego-Nieprawidłowości na rynku finansowym a ochrona konsumenta, A. Jurkowska-Zeidler, J. Monkiewicz, E. Rutkowska-Tomaszewska, T. Bednarczyk, A. Sopoćko (red.), Rzecznik Finansowy, Warszawa, https://rf.gov.pl/pdf/DKN_Raport_nieprawidlowosci_wrzesien2019.pdf [dostęp 22.06.2020].

Rutkowska-Tomaszewska E., Paleczna M., 2018, Idea odpowiedzialnego kredytowania na rynku niebankowych kredytów konsumenckich w Polsce, ,internetowy Kwartalnik Antymonopolowy i Regulacyjny", nr 6.

Rządowy projekt ustawy o zmianie niektórych ustaw w celu przeciwdziałania lichwie, Druk sejmowy 3600 dostępny na: https://www.sejm.gov.pl/Sejm8.nsf/PrzebiegProc.xsp?nr=3600 [dostęp 9.09.2020].

Sieradzka M., 2008, Wyktadnia pojęcia „zbiorowy interes konsumentów” na tle orzecznictwa, „Glosa”, nr 3.

Sieradzka M., 2014, Art. 24. 1. [Praktyki naruszajace zbiorowe interesy konsumentów - uwagi ogólne], [w:] K. Kohutek, M. Sieradzka, Ustawa o ochronie konkurencji i konsumentów. Komentarz, Wydawnictwo Wolters Kluwer, Warszawa.

Sieradzka M., 2016, Ochrona konkurencji i konsumentów. Komentarz do zmian wprowadzonych ustawa z dnia 5 sierpnia 2015 r. o zmianie ustawy o ochronie konkurencji i konsumentów oraz niektórych innych ustaw, LEX/el.

Sroczyński J., 2016, Misselling: nowy rodzaj zakazanej praktyki naruszającej zbiorowe interesy konsumentów, „Przegląd Ustawodawstwa Gospodarczego”, nr 4.

Szakun M., 2019, Misselling na rynku ustug finansowych (pojęcie, geneza i prawne mechanizmy przeciwdziałania temu zjawisku w świetle doświadczeń krajowych i międzynarodowych), Raport Doradczego Komitetu Naukowego - Nieprawidłowości na rynku finansowym a ochrona konsumenta, A. Jurkowska-Zeidler, J. Monkiewicz, E. Rutkowska-Tomaszewska, T. Bednarczyk, A. Sopoćko (red.), Rzecznik Finansowy, Warszawa, https://rf.gov.pl/pdf/DKN_Raport_nieprawidlowosci_wrzesien2019.pdf [dostęp 22.06.2020].

Szpringer W., 2009, Społeczna odpowiedzialność banków. Między ochronq konsumenta a ostona socjalna, Wydawnictwo Wolters Kluwer, Warszawa. 
Ustawa z dnia 12 maja 2011 r. o kredycie konsumenckim, T.j. Dz.U. 2019, poz. 1083 i poz. 1497.

Ustawa z dnia 15 sierpnia 2015 r. o zmianie ustawy o nadzorze nad rynkiem finansowym oraz niektórych innych ustaw, Dz.U. 2015, poz. 1357.

Ustawa z dnia 15 września 2000 r. Kodeks spółek handlowych, T.j. Dz.U. 2020, poz. 1526.

Ustawa z dnia 16 lutego 2007 r. o ochronie konkurencji i konsumentów, T.j. Dz.U. 2020, poz. 1076.

Ustawa z dnia 23 kwietnia 1964 r. - Kodeks cywilny, Dz.U. 2019, poz. 1145.

Ustawa z dnia 23 sierpnia 2007 r. o przeciwdziałaniu nieuczciwym praktykom rynkowym, T.j. Dz.U. 2017, poz. 2070.

Uzasadnienie do Rządowego projektu ustawy o zmianie ustawy o nadzorze nad rynkiem finansowym, ustawy - Prawo bankowe oraz niektórych innych ustaw, http://www.sejm.gov.pl/Sejm7.nsf/druk.xsp?nr=3460 [dostęp 22.06.2020].

Wesołowska I., 2014, Przesłanki uznania praktyki za naruszająca zborowe interesy konsumentów, „IKAR”, nr 4.

Wyrok Sądu Najwyższego z dnia 10 kwietnia 2008 r., III SK 27/07, OSNP 2009, nr 13-14, poz. 188.

Wyrok Sądu Okręgowego w Warszawie - XVII Wydział Gospodarczy z dnia 23 maja 2011 r., sygn. akt XVII AmA 212/09.

Wyrok Sądu Okręgowego w Warszawie Sąd Ochrony Konkurencji i Konsumentów z dnia 13 stycznia 2009 r., sygn. akt XVII Ama 26/08.

Wyrok Trybunału Sprawiedliwości Unii Europejskiej z dnia 26 marca 2020 r., C-779/18 (ECLI:EU:C:2020:236).

\title{
REFINANCING OF CREDIT GRANTED TO A CONSUMER BY VARIOUS ENTITIES WITH CAPITAL OR PERSONAL LINKS AS A PRACTICE INFRINGING COLLECTIVE CONSUMER INTERESTS
}

\begin{abstract}
There are various irregularities in creditors' actions, one of which is the refinancing of consumer credit granted to the consumer by various entities with capital or personal links. This is a phenomenon which has become apparent in the activities of lenders over the last few years and has been the subject of analyses by both the Financial Ombudsman and the President of the Office for Competition and Consumer Protection. The purpose of this article is to present the phenomenon of refinancing a credit granted to a consumer by various entities affiliated by capital or personally as an attempt to circumvent the application of Article 36a and Article 36c of the Act of 12 May 2011 on consumer credit and thus a practice infringing the collective interests of consumers pursu-ant to Article 24(1) and (2) of the Act of 16 February 2007 on Competition and Consumer Protection. The aim of the study is to present the phenomenon of refinancing a credit granted to a consumer by various entities with capital or personal links and to consider this phenomenon as a prohibited practice infringing the collective interests of consumers.
\end{abstract}

Keywords: reafinance a credit, practices infringing collective consumer interests, consumer protection, consumer credit. 